\title{
Sucrose hydrolysis catalyzed by auto-immobilized invertase into intact cells of Cladosporium cladosporioides
}

\section{Ana Cláudia Santana de Almeida}

Departamento de Engenharia Química

Universidade Federal de Pernambuco

Cidade Universitária

P.O. BOX: 50670-901

Recife, Pernambuco, Brasil

Tel: 558132710095

Fax: 558132710095

E-mail: anacsa@chesf.gov.br

\section{Luciares Costa de Araújo}

Departamento de Engenharia Química Universidade Federal de Pernambuco

Cidade Universitária

P.O. BOX: 50670-901

Recife, Pernambuco, Brasil

Tel: 558132710095

Fax: 558132710095

E-mail: luciares14@yahoo.com.br

\section{Andressa Mendes Costa}

Departamento de Engenharia Química

Universidade Federal de Pernambuco

Cidade Universitária

P.O. BOX: 50670-901

Recife, Pernambuco, Brasil

Tel: 558132710095

Fax: 558132710095

E-mail: andressagatis@yahoo.com.br

\section{César Augusto Moraes de Abreu \\ Departamento de Engenharia Química \\ Universidade Federal de Pernambuco Cidade Universitária P.O. BOX: 50670-901 \\ Recife, Pernambuco, Brasil Tel: 558132710095 Fax: 558132710095 \\ E-mail: césar@ufpe.br}

Maria Alice Gomes de Andrade Lima

Departamento de Engenharia Química

Universidade Federal de Pernambuco

Cidade Universitária

P.O. BOX: 50670-901

Recife, Pernambuco, Brasil

Tel: 558132710095

Fax: 558132710095

E-mail: magal@ufpe.br

\author{
Maria de Los Angeles Perez Fernandez Palha* \\ Departamento de Engenharia Química \\ Universidade Federal de Pernambuco \\ Cidade Universitária \\ P.O. BOX: 50670-901 \\ Recife, Pernambuco, Brasil \\ Tel: 558132710095 \\ Fax: 558132710095 \\ E-mail: angeles@ufpe.br
}

Keywords: Cladosporium cladosporioides, factorial planning, invertase.

Financial support: $\mathrm{CNPq}$ (Conselho Nacional de Desenvolvimento Científico e Tecnológico). 
The enzyme known as invertase (E.C. 3.2.1.26 - $\beta$-Dfructofuranosidase) catalyzes the sucrose hydrolysis producing an equimolar mixture of glucose and fructose named inverted sugar. The fungus Cladosporium cladosporioides has invertase as its constituent. Hence, its use as a natural immobilized support for the invertase produces interesting results for the enzyme. The present work has the objective of determining the optimum operational conditions of auto-immobilized invertase, as well as its kinetic parameters $\left(K_{M}\right.$ and $\left.V_{\text {max }}\right)$. A complete $2^{3}$ factorial planning was done for the evaluation of such parameters. Temperature, $\mathrm{pH}$ and agitation level were the studied variables. The hydrolysis percentage was the monitored result. Batch tests in optimum conditions were done to determine the kinetic parameters. Temperature of $70^{\circ} \mathrm{C}, \mathrm{pH} 6$ and agitation of $170 \mathrm{rpm}$ were the established conditions for the hydrolysis process. The auto-immobilized invertase presented a $K_{M}$ of $447 \mathrm{mM}$ and $V_{\max }$ of $2,805 \mathrm{mmol} / \mathrm{min}$.

The sucrose is a natural sweetener, traditionally, used in human nourishment due to its pleasant taste, nutritious value and low cost production. The sugar cane is one of the most important sucrose sources, containing until 20\% wt sucrose (Glazer and Nikaido, 1995). Sucrose hydrolysis produces a fructose and glucose equimolar mixture named inverted sugar, which has higher edulcorant power. The inverted sugar is incorporated more easily in industrial preparations and has more added value than sucrose (Chou and Jasovsky, 1993). Even though the Brazilian sucrose production is the largest in the world, its production of inverted sugar is not sufficient for the Brazilian demand. However, due to the sucrose low market value, the research on methods to produce inverted sugar from sugarcane sucrose has increased in interest.

Acid and enzymatic hydrolysis have been identified as chemical and biochemical ways to sucrose inversion (disaccharide) into glucose and fructose (soluble monosaccharide). The acidity produced in the acid hydrolysis may be caused by an acid direct action (homogeneous hydrolysis) or a $\mathrm{H}^{+}$cationic resin liberation (heterogeneous hydrolysis). Homogeneous hydrolysis is an economic process, in which the acid to be chosen depends on the final product compatibility. However, syrups obtained in this process are highly coloured due to the extreme reaction conditions ( $\mathrm{pH}$ and temperature) (Arruda and Vitole, 1999). On the other hand, the acidity promoted by cationic resin can cause sugar loss through degradation, leading to hydrometil furfural formation (HMF) causing the syrup to be coloured.

The heterogeneous hydrolysis catalyzed by invertase produces a high quality product with low ashes, colour and containing HMF (Rodrigues et al. 2000). The high cost of invertase production process, together with the low process extraction yield and purification have been limiting factors for the use of enzymatic hydrolysis in industrial processes.

However microorganisms do not release the produced enzyme to the medium, keeping it jointed to periplasmic cell space. Therefore, the biomass utilization of fungus Cladosporium cladosporioides, as a natural support for invertase (auto-immobilization), is a low cost technology with good results. This offers great operational stability to the enzyme, allowing it to be reused without significant activity losses (Coutinho Filho et al. 1999; Costaglioli et al. 1997).

The bioprocess production of inverted sugar, as any other biotechnological process, is very complex due to the number of variables involved. Hence, a balanced environment with optimum temperature, $\mathrm{pH}$, agitation and aeration is necessary to reach a good productivity (Blanch and Clark, 1997).

The factorial planning technique allows the correlation between the independent variables and dependent ones by a minimum number of assays. This is a technique used on studies that involve different variables. Factorial planning method associated to a response surface analysis is the statistic tool based theory. It gives reliable information on the process, minimizes empirism, which involves trial and error techniques (Neto et al.1995). By this planning technique, it is possible to evaluate the independent variables influence on the dependent variables, as well as the interaction between both. An appropriate probabilistic model was obtained using the variance analysis. This model allows determining the independent variables values to optimize the bioprocess performance (Rodrigues et al. 2000).

Hence, this work objective is to apply the factorial planning method to determine the optimum conditions to sucrose enzymatic hydrolyses, using the auto-immobilized enzyme in the fungus Cladosporium cladosporioides cellular mass, and to determine the kinetic parameters $\mathrm{K}_{\mathrm{M}}$ and $\mathrm{V}_{\text {max }}$.

\section{MATERIALS AND METHODS}

\section{Microorganism and culture conditions}

Cladosporium cladosporioides strain URM 4331 was obtained from the culture collection of the Mycology Department of the Universidade Federal de Pernambuco, Brazil. The culture was stored refrigerated in a Potato Dextrose Agar medium containing (g/l): potato infusion dehydrated, 4.0; dextrose, 20.0 and agar, 15.0 and chopped every 30 days. Its fungi form can be observed in Figure 1a.

*Corresponding author 
To observe the fungus growth, there were inoculated approximately $10^{6}$ conidia in $250 \mathrm{ml}$-erlenmeyers flasks containing $100 \mathrm{ml}$ of the semisynthetic medium Czapeck. The composition of this medium was $(\mathrm{g} / \mathrm{l}): \mathrm{NaNO}_{3}, 3.0$; $\mathrm{KCl}, 0.5 ; \mathrm{MgSO}_{4} \cdot 7 \mathrm{H}_{2} \mathrm{O}, 0.5 ; \mathrm{FeSO}_{4} \cdot 7 \mathrm{H}_{2} \mathrm{O}, 0.01 ; \mathrm{K}_{2} \mathrm{HPO}_{4}$, 1.0; Sucrose, 30.0. The fungus grew under a constant 300 rpm agitation, at ambient temperature of $28 \pm 2^{\circ} \mathrm{C}$ during 20 days. The fungus growth was monitored by measuring the $\mathrm{pH}$ levels and through pureness tests for microbial contaminants via microscope's observations. The applied agitation allowed the "pellets" formation with an average diameter of $0.132 \mathrm{~cm}$, which can be observed in Figure 1b. These "pellets" were the supports for the enzyme used as biocatalyst on the hydrolysis process.

\section{Hydrolysis process optimization}

The enzymatic hydrolysis experiments were carried out in discontinued systems (batch system), with and without agitation, using substrate solutions of sucrose $(50 \mathrm{~g} / 1$ of concentration) prepared using a buffer solution consisting of sodium acetate $0.1 \mathrm{M}, \mathrm{pH} 4$ and 6 . For the hydrolysis experiments, 3 g-cells pellets were incubated in $50 \mathrm{ml}$ erlenmeyers flasks containing $30 \mathrm{ml}$ of sucrose solution. Those samples were submitted to the factorial planning assays for $180 \mathrm{~min}$.

For the sucrose hydrolysis process optimization, a complete factorial planning in three levels $\left(2^{3}\right)$ was applied, totalizing eight assays, in duplicates, done at random. Table 1 illustrates the values of temperature, $\mathrm{pH}$ and agitation (in rpm) used in the experiments.

The experiments were monitored by the hydrolysis percentage. This percentage was calculated using the following formula:

Hydrolysis Percentage $=[$ TRS $] / \mathrm{S}_{\mathrm{o}} \times 100 \%$

in which TRS is the Total Reductant Sugar (glucose + fructose), in $\mathrm{mmol}$; and, $\mathrm{S}_{\mathrm{o}}$ is the initial sucrose concentration, in mmol.

The reductant sugar measurement (glucose and fructose) was done by DNSA method (Acid Dinitrosalicilic). This method is a variation of the original one (Miller, 1959). According to this method, the reductant sugar reduces DNSA, which produces forming orangeish colour complexes, which can be quantified by spectrofotometry in the $540 \mathrm{~nm}$ band. A standard curve containing glucose allows the association of absorbance with the concentration of hydrolysis reaction products.

\section{Kinetic studies}

The kinetics of the auto-immobilized invertase was analyzed by the initial reaction rate method, according to Michaelis-Menten kinetic model. The parameters $\mathrm{V}_{\max }$ and $\mathrm{K}_{\mathrm{M}}$ were determined, using the optimal experiment conditions.
As invertase is auto-immobilized in the fungus, it was necessary to determine the fungi mass concentration that optimizes the hydrolysis process. Previous studies have shown that the best concentration for the process is $100 \mathrm{~g} / \mathrm{l}$.

The kinetic tests were done in batch reactor, under optimum conditions obtained from factorial planning. The autoimmobilized enzyme was incubated into different sucrose concentrations $(20,40,60,80,100,200,300,400,500$ and $600 \mathrm{~g} / \mathrm{l})$ during three hours. Samples were collected in intervals of $20 \mathrm{~min}$ to measure the TRS content.

The reaction rate for each experiment was calculated using

$\mathrm{V}=[\mathrm{TRS}] / \mathrm{t}$

in which $\mathrm{V}$ is the reaction rate, given in $\mathrm{mmol} / \mathrm{min}$; and, $\mathrm{t}$ is the time reaction, given in minutes.

\section{RESULTS AND DISCUSSION}

\section{Hydrolysis process optimization}

Table 2 presents the hydrolysis assays conditions for $2^{3}$ factorial planning, as well as the results obtained. The results were given in terms of hydrolysis percentage. According to this table, during assay 1, the process variables (agitation, $\mathrm{pH}$ and temperature) were used at their lowest values, resulting in $35.16 \%$ hydrolysis conversion. However, when process variables were used in their highest levels (assay 8), a 94.17\% hydrolysis conversion were obtained.

The main effects of each process variable, and the ones that resulted due to the interaction among them, were calculated using the software Statistic for Windows version 5.0. The results are presented on the Table 3 .

According to this table, every variable is significant and has positive effects, i.e., for the studied conditions, the highest value of these variables favours the hydrolysis process.

It can be noted that when $\mathrm{pH}$ increases from 4 to 6 , there is an average gain of $40.84 \%$ in the hydrolysis percentage. This result suggests that microbiological enzymes are more active in this $\mathrm{pH}$ interval what makes the cells feasible. However, for the auto-immobilized invertase in Cladosporium cladosporioides cells, the maximum activity occurs when the $\mathrm{pH}$ is around 6 , as it can be observed in the Figure 2, in which the hydrolysis percentual as a function of $\mathrm{pH}$ and agitation level is analyzed.

It is also observed that when the temperature increases from $50^{\circ} \mathrm{C}$ to $70^{\circ} \mathrm{C}$, there is an average gain of hydrolysis percentage of approximately $10.52 \%$. However, when the temperature is set beyond this value, there is a decrease in the enzyme activity. This activity decrease is associated to a reduction in the enzyme stability due to protein denaturation. According to the response surface shown in 
the Figure 3, it can be observed that the hydrolysis optimum temperature is $70^{\circ} \mathrm{C}$.

Also, it was noted that due to agitation there was an increase in activity of approximately $8 \%$. This increase in activity is caused by the reduction of the mass transfer resistance due a greater liquid-solid surface contact. However, the agitation during the hydrolysis reaction does not influence hydrolysis as much as the other variables.

For the Saccharomyces cerevisiae yeast invertase, the optimum $\mathrm{pH}$ occurs in the 3.5 to 6.0 interval. However, for Pichia and Torulospora, it depends on the substrate concentration and buffer used (Rodriguez et al. 1995; Oda and Tonomura, 1994). For Candida utilis, at $\mathrm{pH} 5.5$, the range of optimum temperature was $60-75^{\circ} \mathrm{C}$ (Chávez et al. 1997). These results show different $\mathrm{pH}$ values for each invertase, for different microorganisms that produce it. The temperature that optimizes the hydrolysis process is a function of the enzyme type and experimental conditions; values within 45 to $73^{\circ} \mathrm{C}$ interval have been reported (Bergamasco et al. 2000; Oda and Tonomura, 1994).

\section{Kinetic parameters determination $\left(K_{M}\right.$ and $\left.V_{\text {max }}\right)$}

The kinetic parameters of enzymatic reaction were calculated by the Lineweaver-Burk linerization using the Michaelis-Menten kinetic model. For the auto-immobilized enzyme it was obtained a $K_{M}$ of $447 \mathrm{mM}$ and $V_{\max }$ of 2,805 $\mathrm{mmol} / \mathrm{min}$. These values were obtained using linear regression of the curve $1 / \mathrm{V}$ versus $1 / \mathrm{S}$ shown in the Figure 4. The $K_{M}$ value was higher than those mentioned in literature for free invertase (24 mM) (Akgöl et al. 2001); (46 mM) (Tanriseven, 2001); (227 mM) (Rubio et al. 2002). The substrate has more difficulty to access the active zone of auto-immobilized enzyme, thus, it can be the cause for such a change in the enzyme affinity for the substrate $\left(\mathrm{K}_{\mathrm{M}}\right)$. Regarding to the free enzyme, were achieved tests with the invertase Sigma $^{\mathrm{O}} \mathrm{V}$ Level, the values obtained were a $V_{\max }$ of $2,047 \mathrm{mmol} / \mathrm{min}$ and a $K_{m}$ of $73,2 \mathrm{mM}$. The $\mathrm{V}_{\max }$ presented the same order, however the $\mathrm{K}_{\mathrm{m}}$ of the autoimmobilized enzyme was nearly six times bigger then the $\mathrm{K}_{\mathrm{m}}$ of the free enzyme. This suggests that the catalytic function of these enzymes is not damaged by immobilization. Furthemore, the auto-immobilized enzyme can be reused many times, keeping its quality and quantity patterns. Such results are different from the mentioned in literature (Danisman et al. 2004; Kiralp et al. 2003) because of the several methodologies of immobilization, the enzyme lineage, the enzyme activity per mg of protein, among other factors.

\section{CONCLUDING REMARKS}

The factorial planning led to the identification of the variables with more influence in the sucrose hydrolysis process by the enzymatic route. The optimum operational condition was: temperature of $70^{\circ} \mathrm{C}, \mathrm{pH} 6$ and moderate agitation. These conditions agree with other works mentioned in the literature, which uses agitation below 300 rpm, $\mathrm{pH}$ between 4.5 and 6 and temperatures around $60^{\circ} \mathrm{C}$ (Blanch and Clark, 1997; Chávez et al. 1997).

For the kinetics applied of the auto-immobilized invertase in the fungus Cladosporium cladosporioides, the Michaelis-Menten kinetic model represents satisfactorily this enzyme behaviour. The value of $\mathrm{K}_{\mathrm{M}}$ obtained for autoimmobilized enzyme was higher than those for soluble ones mentioned in literature. This result can be related to the mass transport resistance imposed by cellular structure, which does not occur with the soluble invertase.

In spite of the diffusive limitations of cellular structure, the cell acts as the immobilization support of the enzyme. This immobilization seems to improve the invertase operational stability which justifies the use of these cells in industrial bioreactors instead of the soluble invertase.

\section{REFERENCES}

AKGÖL, Sinan; KAÇAR, Yasemin; DENIZLI, Adil and ARICA, M.Y. Hydrolysis of sucrose by invertase immobilized onto novel magnetic polyvinylalcohol microspheres. Food Chemistry, January 2001, vol. 74, no. 3, p. 281-288.

ARRUDA, L.M.O. and VITOLE, M. Characterization of invertase entrapped into calcium alginate beads. Applied Biochemistry and Biotechnology, July 1999, vol. 81, no. 1, p. 23-33.

BERGAMASCO, R.; BASSETTI, F.J.; MORAES, F.F. and ZANIN, G.M. Characterization of free and immobilized invertase regarding activity and energy of activation. Biochemical Engineering Journal, Dec. 2000, vol. 17, no. 4-7, p. 873-880.

BLANCH, Harvey W. and CLARK, Douglas S. Biochemical Engineering. $1^{\text {st }}$ ed. New York, Marcel Dekker, 1997. 720 p. ISBN0-82-47 0099-6.

CHÁVEZ, Francisco P.; RODRIGUEZ, Luis; DÍAZ, Joaquín; DELGADO, Julio M. and CREMATA, José A. Purification and characterization of invertase from Candida utilis: comparison with natural and recombinant yeast invertases. Journal of Biotechnology, January 1997, vol. 53, no. 1, p. 67-74.

CHOU, C.C. and JASOVSKY, G.A. Advantages of EcosorbTM precoats in liquid sugar production. International Sugar Journal, July 1993, vol. 95, no. 1138, p. $425-430$.

COSTAGLIOLI, Patrícia; MEILHOC, Eliane; JANATOVA, Ivana; KLEIN, Ronald D. and MASSON, Michel J. Section of invertase from Sachwannyomices occidentalis. Biotechnology Letters, July 1997, vol. 19, no. 7, p. 623-627. 
COUTINHO Filho, U.; HORI, C.E. and RIBIERO, E.J. Influence of reaction products in inversion of sucrose by invertase. Brazilian Journal of Chemical Engineering, June 1999, vol. 16, no. 2, p.149-153.

DANISMAN, Tarik; TAN, Sema; KACAR, Yasemin and ERGENE, Aysun. Covalent immobilization of invertase on microporous pHEMA-GMA membrane. Food Chemistry, May 2004,vol. 85, no. 3, p. 461-466.

GLAZER, Alexander N. and NIKAIDO, Hiroshi. Microbial Biotechnology: Fundamentals of Applied Microbiology. $2^{\text {nd }}$ ed., New York, W.H. Freeman and Company, 1995. 640 p. ISBN 0-71-67 2608-4.

KIRALP, S.; TOPPARE, L. and YAGCI Y. Immobilization of invertase in copolymers of thiophene functionalized methyl ester with pyrrole. Synthetic Metals, April 2003, vol. 135 , p. $79-80$.

MILLER, Gail L. Use of dinitrosalicylic acid reagent for determination of reducing sugar. Analytical Chemistry, March 1959, vol. 31, no. 3, p. 426-428.

NETO, Benício B.; SCARMINIO, Ieda S. and BRUNS, Roy E. Planejamento e Otimização de Experimentos. Campinas, Ed. Unicamp, 1995. 299 p. ISBN 85-26 803360 .

ODA, Yuji and TONOMURA, Kenji. Purification and characterization of invertase from Torulospora pretoriensis YK-1. Bioscience Biotechnology and Biochemistry, November 1994,vol. 58, no. 11, p. 1155-1157.

RODRIGUES, Marili V.N.; RODRIGUES, Rodney A.F.; SERRA, Gil E.; ANDRIETTA, Silvio R. and FRANCO, Telma T. Produção de xarope de açúcar invertido obtido por hidrólise heterogênea através de planejamento experimental. Ciência e Tecnologia dos Alimentos, April 2000, vol. 20, no. 1, p. 103-109.

RODRIGUEZ, J.; PEREZ, J.A.; RUIZ, T. and RODRIGUEZ, L. Characterization of the invertase from Pichia anomala. Biochemical Journal, February 1995, vol. 306, p. 235-239.

RUBIO, María C.; RUNCO, Rosa and NAVARRO, Antonio R. Invertase from a strain of Rhodotorula glutinis. Phytochemistry, July 2002, vol. 61, p. 605-609.

TANRISEVEN, Aziz. Immobilization of invertase within calcium alginate gel capsules. Process Biochemistry, February 2001, vol. 36, no. 11, p. 1081-1083. 


\section{APPENDIX}

Tables

Table 1. Levels of studied variables in $2^{3}$ factorial planning, applied to sucrose enzymatic hydrolysis.

\begin{tabular}{|c|c|c|}
\hline Variables & Limits & \\
\hline & Lower & Upper \\
\hline Agitation (A), rpm & 0 & 170 \\
\hline $\mathrm{pH}$ & 4 & 6 \\
\hline Temperature $(\mathrm{T}),{ }^{\circ} \mathrm{C}$ & 50 & 70 \\
\hline
\end{tabular}

Table 2. $2^{3}$ factorial planning matrix for the analysis of agitation level, $\mathrm{pH}$ and temperature.

\begin{tabular}{|c|c|c|c|c|c|c|}
\hline Assay & $\mathbf{A}(\mathbf{r p m})$ & $\mathbf{p H}$ & $\mathbf{T}\left({ }^{\circ} \mathbf{C}\right)$ & \multicolumn{2}{|c|}{ Hydrolysis \% } & Average \% \\
\hline $\mathbf{1}$ & 0 & 4 & 50 & 33.52 & 36.80 & 35.16 \\
\hline $\mathbf{2}$ & 170 & 4 & 50 & 43.35 & 47.73 & 45.54 \\
\hline $\mathbf{3}$ & 0 & 6 & 50 & 65.21 & 71.77 & 68.49 \\
\hline $\mathbf{4}$ & 170 & 6 & 50 & 77.23 & 81.60 & 79.42 \\
\hline $\mathbf{5}$ & 0 & 4 & 70 & 42.26 & 38.98 & 40.62 \\
\hline $\mathbf{6}$ & 170 & 4 & 70 & 45.54 & 47.73 & 46.63 \\
\hline $\mathbf{7}$ & 0 & 6 & 70 & 91.44 & 87.07 & 89.26 \\
\hline $\mathbf{8}$ & 170 & 6 & 70 & 95.81 & 93.53 & 94.17 \\
\hline
\end{tabular}


Table 3. Calculated effects for the $2^{3}$ factorial planning.

\begin{tabular}{|c|c|}
\hline Effect & Estimation + Standard Error \\
\hline Main effect $\quad$ Total Average & $62.41 \pm 0.73^{*}$ \\
\hline Agitation (A) & $8.06 \pm 1.46^{*}$ \\
$\mathrm{pH}$ & $40.84 \pm 1.46^{*}$ \\
Temperature (T) & $10.52 \pm 1.46^{*}$ \\
\hline Effect of the interaction of two factors & $-0.14 \pm 1.46^{*}$ \\
\hline Agitation vs. pH & $-2.59 \pm 1.46^{*}$ \\
Agitation vs. Temperature & $7.24 \pm 1.46^{*}$ \\
\hline pH vs. Temperature & \\
\hline Effect of the interaction of three factors & $-0.41 \pm 1.46^{*}$ \\
\hline Agitation vs. pH vs. Temperature & \\
\hline
\end{tabular}

* significant values (95\% confidence interval) 


\section{Figures}
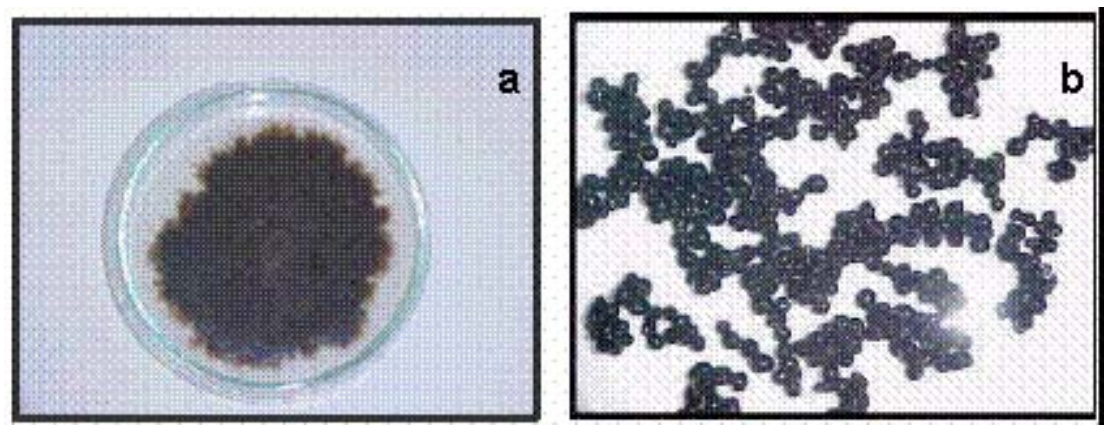

Figure 1a. Fungi form of Cladosporium cladosporioides.

Figure 1b. Cladosporium cladosporioides' pellets.

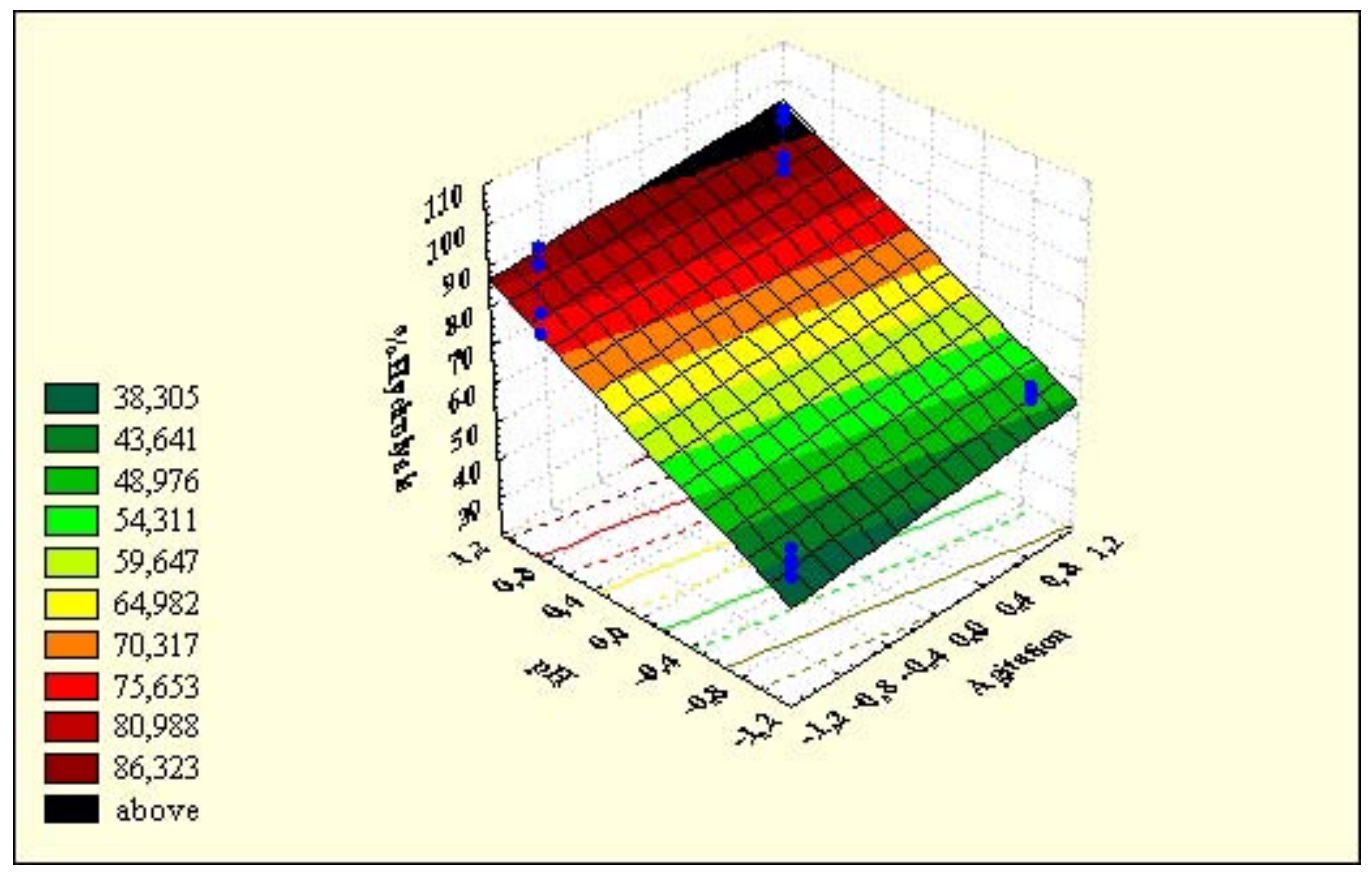

Figure 2. Hydrolysis percentage profile as a function of $\mathrm{pH}$ and agitation. 


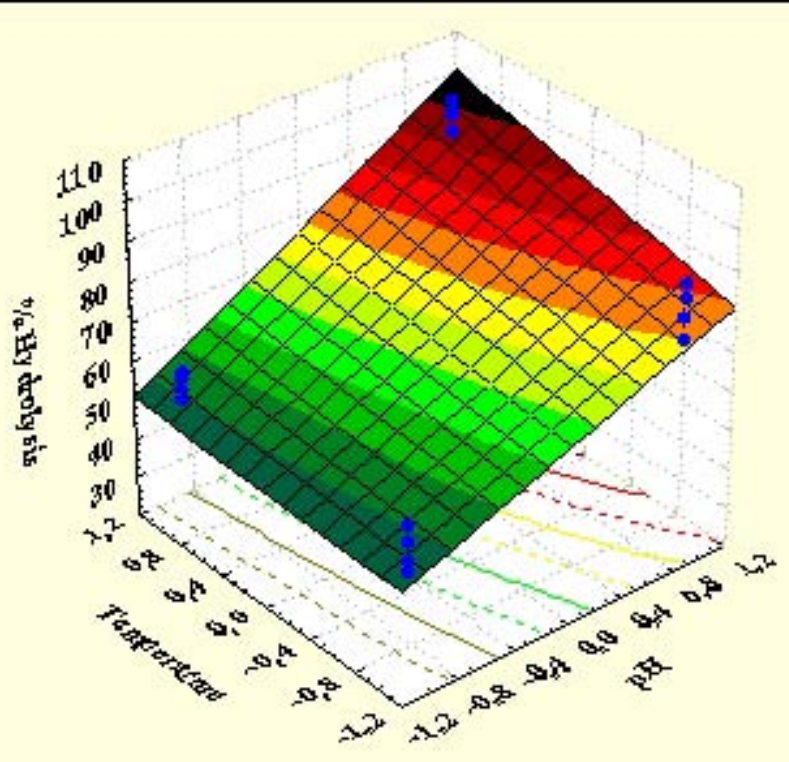

above

Figure 3. Hydrolysis percentage profile as a function of $\mathrm{pH}$ and temperature.

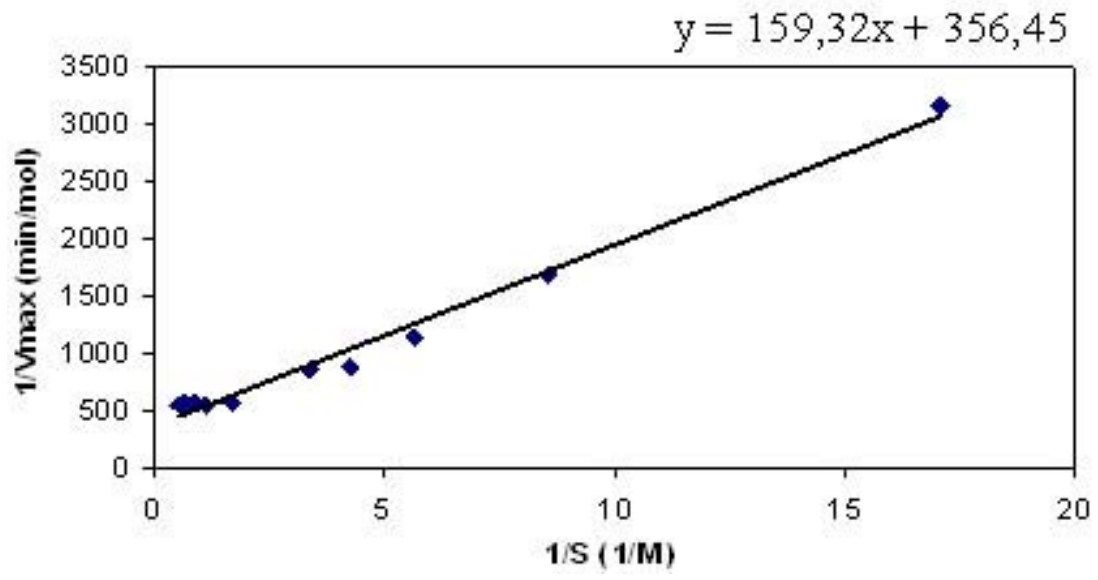

Figure 4. Lineweaver, Burk linearization for auto-immobilized invertase. 